\title{
Childhood malnutrition and bacteraemia at a tertiary hospital in
}

\section{Malawi}

Victoria Temwanani Mukhula ${ }^{1 a}$, Philliness Prisca Harawa ${ }^{1,2 a}$, Chisomo Phiri ${ }^{3}$, Stanley Khoswe $^{3}$, Jessica Chaziya ${ }^{2}$, Emmie Mbale ${ }^{2,3}$, Caroline Tigoi ${ }^{3}$, Pui-Ying Iroh Tam ${ }^{1,2,4 a}$ Robert Bandsma ${ }^{3,5 a}$, Wieger Voskuijl ${ }^{3,6}$ a

Affiliations

1. Malawi-Liverpool Wellcome Trust Clinical Research Programme, P.O Box 30096, Chichiri, Blantyre 3.

2. Department of Paediatrics and Child Health Department, Kamuzu University of Health Sciences (formerly College of Medicine), Private Bag 360, Chichiri, Blantyre 3.

3. The Childhood Acute Illness \& Nutrition (CHAIN) Network, Nairobi, Kenya

4. Liverpool School of Tropical Medicine, Liverpool, United Kingdom

5. Department of Nutritional Sciences, Faculty of Medicine, University of Toronto, Toronto, Canada

6. Amsterdam Centre for Global Child Health, Emma Children's Hospital, Amsterdam University Medical Centre, Amsterdam, the Netherlands

${ }^{\text {a }}$ Authors contributed equally to the manuscript.

Corresponding author: Dr. Victoria Temwanani Mukhula.

Email: vmukhula@mlw.mw 


\section{Abstract}

Background: Malnutrition increases risk of acquiring infections but clinical characteristics and hospital outcomes among children in low resource settings with high rates of antimicrobial resistance have not been clearly described.

Aim: Our main aim was to ascertain prevalence of bacteraemia in hospitalised children at Queen Elizabeth Central Hospital, Malawi.

Methods: We conducted a secondary analysis of a prospective study of children who had a blood culture collected during hospitalisation.

Results: Out of 175 children who had blood cultures collected during hospitalisation, 75 had severe acute malnutrition (SAM), 31 moderate acute malnutrition (MAM), and 69 no acute malnutrition (NAM). Twelve (7\%) had bacteraemia (8 SAM, 1 MAM, 3 NAM) and seventeen (10\%) died (14 SAM, 2 MAM, 1 NAM). Fever, vomiting and convulsions were least common in SAM $(69 \%, 37 \%, 1 \%)$ compared to MAM $(90 \%, 81 \%, 10 \%)$ and NAM $(99 \%, 46 \%, 29 \%$; $\mathrm{p}<0.001)$ children. Mortality was significantly higher in those with than without bacteraemia (33\% vs $8 \%, p=0.004)$. Most common isolates were Salmonella Typhimurium (31\%) and Escherichia coli (23\%). High rates of bacterial resistance were noted to gentamicin (58\%), a first-line antibiotic, and ceftriaxone (33\%), a second-line antibiotic.

Conclusions: Mortality and bacteraemia rates are highest in hospitalised children with SAM. Despite this, SAM children do not present with typical clinical features, including fever, vomiting and convulsions. Given the high rate of antimicrobial resistance in this setting, a high index of infection clinical suspicion, awareness of local susceptibility patterns and evidence-based antibiotic guidelines are needed to optimise clinical care and antimicrobial stewardship. 
medRxiv preprint doi: https://doi.org/10.1101/2021.08.19.21262269; this version posted August 21, 2021. The copyright holder for this preprint (which was not certified by peer review) is the author/funder, who has granted medRxiv a license to display the preprint in perpetuity.

All rights reserved. No reuse allowed without permission.

Key words: Bacteraemia, malnutrition, antimicrobial resistance, mortality.

\section{Lay Summary}

Malnutrition increases the risk of having an infection but symptoms and hospital outcomes among children with malnutrition, in countries like Malawi with high rates of antimicrobial resistance, have not been clearly described. This study describes a study of children who had a blood culture collected during admission to Queen Elizabeth Central Hospital, Malawi. Of 175 children who had blood cultures collected, $12(7 \%)$ had a bacteria found ('bactaeriemia') and 17 (10\%) died. Fever, vomiting and convulsions were significantly less common in severe malnutrition compared to children with moderate malnutrition and those with no malnutrition. Mortality was significantly higher in those with bacteraemia than without. High rates of bacterial resistance were noted to first- and second-line antibiotics. Mortality and bacteraemia rates are highest in hospitalised children with SAM even though they do not present with typical features of bacteraemia. 


\section{Introduction}

Malnutrition is estimated to contribute up to $45 \%$ of all childhood mortality globally, the majority of which are in low- and- middle income countries $(1,2)$. There is a bi-directional relationship between malnutrition and infection. Chronic or recurrent infections, like untreated HIV and diarrhoea, can often contribute to malnutrition. Conversely, due to impaired immune function, malnourished children are at increased risk of infectious diseases, including persistent diarrhoea, pneumonia and bacteraemia (3).

Bacteraemia is defined as the presence of viable bacteria in the circulating blood (4) and diagnosis is confirmed by blood culture. Prevalence of bacteraemia in malnourished children in Africa ranges between 5\%-36\% (5-7). Malnourished children with bacteraemia have an increased risk of poor outcomes including mortality and prolonged hospital stay (8).

Diagnosis of bacteraemia is challenging in low- and- middle income countries due to limited laboratory capacity. Apart from that, malnourished children do not usually display obvious clinical signs of infections like fever $(9,10)$. The World Health Organization (WHO), therefore, recommends empirical treatment with broad spectrum antibiotics for all admitted severely malnourished children to prevent mortality (11). Concurrently, there has been a global increase in the prevalence of antimicrobial resistance in young hospitalised children, irrespective of their nutritional status, which has also been associated with poor clinical outcomes (13).

There is limited recent data evaluating the association between bacteraemia and outcomes in malnourished children, a high risk population $(5,11-15)$. There are no data in Malawi on the prevalence of bacteraemia and its associated outcomes for hospitalised malnourished 
children. Therefore, we collected data on culture and susceptibility profiles in the hospitalised population to inform local Malawian guidelines on rational use of antibiotics among children with malnutrition.

The main objective of this study was to ascertain prevalence of bacteraemia in hospitalised children enrolled in the "Childhood Acute Illness and Nutrition network" (CHAIN-network) cohort study at Queen Elizabeth Central Hospital (QECH) in Malawi, a tertiary hospital which follows WHO recommendations on antimicrobial use in treating malnourished children. The secondary objectives were to determine the blood culture isolates and their susceptibility profiles; and compare clinical characteristics and outcomes among children with and without bacteraemia.

\section{Methodology}

\section{Setting}

The study took place at QECH which is the largest referral hospital located in Blantyre, southern Malawi. It serves an estimated population of 800,000 (16). The paediatric department admits 26,000 patients per year with approximately 1,200 patients served in the nutrition rehabilitation unit $(17,18)$.

\section{Study design}

The CHAIN Network is a collaborative group of investigators which was established in four African (Burkina Faso, Uganda, and Kenya) and two South Asian countries (Bangladesh, Pakistan) to improve child survival and optimise growth and development outcomes of malnourished children in low-resource settings. The main aim of CHAIN was to identify modifiable risk factors that could be targeted by interventions for children at highest risk of mortality, including malnourished children (19). 
medRxiv preprint doi: https://doi.org/10.1101/2021.08.19.21262269; this version posted August 21, 2021. The copyright holder for this preprint (which was not certified by peer review) is the author/funder, who has granted medRxiv a license to display the preprint in perpetuity.

All rights reserved. No reuse allowed without permission.

We conducted a secondary analysis of the CHAIN data from the Malawi site (19). In Malawi, CHAIN recruited hospitalised children aged between 7 days and 24 months between 1 October 2016 and 31 January 2019, and followed them up to 180 days after discharge. Patients were followed during the initial admission and subsequent re-hospitalisations to QECH. Children with a known congenital syndrome, cleft palate, known congenital cardiac disease, known terminal illness e.g. cancer, admitted mainly for surgery or trauma, or likely to require surgery within 6 months were excluded. The CHAIN cohort study collected extensive clinical and follow-up data of all participants.

Our study was a convenience sample where we included all children who were recruited in the CHAIN study and had a blood culture taken during admission, hospital stay or follow-up. We excluded children who did not have a blood culture collected. Written informed consent was provided, and approval was obtained from College of Medicine Research Ethics Committee (COMREC approval number: P.06/16/1969) under Kamuzu University of Health Sciences then called University of Malawi.

\section{Data collection}

We collected data from the CHAIN's Research Electronic Data Capture (REDCap) version 8. Clinical data included anthropometry, admission symptoms and co-morbidities, initial diagnosis, initial treatment received, and hospital stay. Children were stratified by mid upper arm circumference (MUAC) into three nutritional strata: 1) No Acute Malnutrition (NAM), defined as MUAC of $>12.5 \mathrm{~cm}$ for children aged at least 6 months or $>12 \mathrm{~cm}$ for those under 6 months of age; 2) Moderate Acute Malnutrition (MAM), defined as MUAC of $11.5-12.5 \mathrm{~cm}$ for children aged at least 6 months, or $11-12 \mathrm{~cm}$ for $<6$ months of age; and 3) Severe Acute Malnutrition (SAM), defined as MUAC of $<11.5 \mathrm{~cm}$ for those at least 6 months or $<11 \mathrm{~cm}$ for $<6$ months of age, or presence of nutritional oedema regardless of MUAC. 
medRxiv preprint doi: https://doi.org/10.1101/2021.08.19.21262269; this version posted August 21, 2021. The copyright holder for this preprint (which was not certified by peer review) is the author/funder, who has granted medRxiv a license to display the preprint in perpetuity.

All rights reserved. No reuse allowed without permission.

Corresponding blood cultures and antimicrobial susceptibility results were extracted from the Malawi-Liverpool Wellcome Trust laboratory system, following microbiological testing procedures described in detail elsewhere (20). Blood culture results were described as positive if there was significant growth of a pathogen, and negative if there was either a contaminant or no growth. The following isolates were considered to be contaminants: coagulase-negative Staphylococci, Micrococcus species, Bacillus species and diptheroids. Isolates from blood cultures taken after 48 hours of hospital stay were regarded as nosocomial infections while those from within 48 hours of admission were considered to be community-acquired infections.

\section{Statistical analyses}

We exported data into Microsoft Excel 2007 and analyzed in R Studio Version 1.2.5001. Mean, standard deviation (SD) and ranges were used for continuous variables and with an ANOVA p-value. Counts and percentages were used to describe categorical variables and a Chi-square test was used to compare the differences in the groups. Statistical significance was set at $P<0.05$ with a confidence interval of $95 \%$. Primary outcome was bacteraemia.

\section{Results}

A total of 347 children were enrolled in the CHAIN study and 175 had blood cultures collected during admission: 75 with SAM, 31 MAM and 69 NAM (Figure 1).

Table 1 compares clinical characteristics and outcomes among patients of different nutrition groups. Several significant differences were noted. Children with MAM were the youngest with a mean age of 10 months and NAM were oldest with mean age of 13 months $(p=0.039)$. All nutrition groups had negative mean Weight-for-Height $Z$ (WHZ) score: NAM: -0.6 SD, MAM: -2.0 SD, SAM: -3.2 SD. HIV prevalence confirmed by DNA PCR testing was highest in SAM children (9\%) followed by MAM (1\%) and none in NAM. Having fever on admission was least common in SAM (69\%) compared to MAM (90\%) and NAM (99\%). Vomiting and 
medRxiv preprint doi: https://doi.org/10.1101/2021.08.19.21262269; this version posted August 21, 2021. The copyright holder for this preprint (which was not certified by peer review) is the author/funder, who has granted medRxiv a license to display the preprint in perpetuity.

All rights reserved. No reuse allowed without permission.

convulsions were least common features among SAM (37\% and $1 \%$ ) compared to MAM (81\% and 10\%) and NAM (46\% and 29\%). Sepsis was the least documented admission clinical diagnosis in children with SAM compared to MAM and NAM at $29 \%, 65 \%$ and $46 \%$, respectively $(p=0.003)$. Thirteen patients had a positive blood culture $(7 \%)$ with significant growth, which was highest among children with SAM (12\%), followed by those with MAM and children with NAM ( $1 \%$ and $2 \%$, respectively). All of thirteen patients with positive blood culture grew bacterial species except one malnourished patient who grew candida. Twentyseven patients $(15 \%)$ grew contaminants. Fever was a more common presentation in patients with a negative blood culture (86\%) compared to those with a positive blood culture $(62 \% ; p=0.017)$, irrespective of their nutritional status. Oral rehydration was highest among children with SAM (43\%) compared with MAM and NAM $(6 \%$ and $0 \%$, respectively; $\mathrm{p}<0.001)$. Children with SAM had significantly longer hospital stays compared to MAM and NAM with mean days of 10,5 and 3 , respectively $(p<0.001)$. Mortality was also highest in children with SAM at $19 \%$ compared to $6 \%$ in MAM and $1 \%$ in NAM $(p=0.002)$.

Table 2 describes characteristics and outcomes of patients with and without bacteraemia, shown through positive and negative blood cultures respectively. More patients with a positive blood culture received antibiotics within 7 days prior to admission than those with negative blood culture at $75 \%$ vs $37 \%(p=0.022)$. Patients with a positive blood culture had significantly higher mortality (33\%) compared to those with a negative blood culture $(8 \%$, $\mathrm{p}=0.004$ ). There were, however, no significant differences in nutrition status and duration of hospital stay between the two groups.

Of the 13 blood cultures that were positive,12 grew bacteria. Salmonella Typhimurium was the most common isolate (24\%), followed by E. coli (18\%). Klebsiella pneumoniae and Candida species were hospital acquired infections which were both isolated in children with SAM (Figure 2). Susceptibility profiles of these isolates to $\mathrm{QECH}$ paediatric first-line antibiotics (penicillin and gentamicin), second-line antibiotics (ceftriaxone and amikacin) and 
medRxiv preprint doi: https://doi.org/10.1101/2021.08.19.21262269; this version posted August 21, 2021. The copyright holder for this preprint (which was not certified by peer review) is the author/funder, who has granted medRxiv a license to display the preprint in perpetuity.

All rights reserved. No reuse allowed without permission.

other commonly prescribed antibiotics (chloramphenicol and ciprofloxacin) are shown in Table 3. From the bacterial isolates, $58 \%$ were resistant to gentamicin, and $33 \%$ to ceftriaxone.

Table 4 shows clinical characteristics of patients discharged compared to those who died. Overall, there was a $10 \%(n=17)$ mortality. Fever was a common clinical characteristic in those who were discharged ( $87 \%)$ compared to those who died $(65 \%, p=0.017)$. Majority of the children who died presented with gastroenteritis $(71 \%)$ compared to those who presented with gastroenteritis but were discharged $(41 \%, \mathrm{p}=0.017)$.

\section{Discussion}

In our study, bacteraemia was highest among children with SAM at $11 \%$ despite having the lowest rates of fever and admission diagnosis of sepsis, which are the classical clinical indications for blood culture collection (Supplementary table 1) (8). Mortality (19\%) was highest among children with SAM compared to other nutrition groups. Our study highlights the need for blood culture collection on hospital admission for all SAM children at an urban tertiary hospital regardless of their presenting clinical characteristics, as they are at the highest risk of mortality.

The mortality rate among children with SAM found in our study is higher than that in a referral hospital in central Malawi, Kamuzu Central Hospital, where mortality was $10.1 \%$ (21). One potential reason for the difference could be because of different geographical locations of the study sites which has an effect on the HIV prevalence with the highest rates in the Southern region (21). HIV is independently associated with death especially in SAM children. In addition, 8.2\% $(\mathrm{n}=54)$ were lost to follow-up during admission in the other study. The mortality was also higher compared to a study in Ethiopia which assessed bacteraemia in children one to fourteen years of age, and had a mortality of $7.1 \%(15)$. This is likely due to the difference in the age of the participants, with our study having a younger population 
medRxiv preprint doi: https://doi.org/10.1101/2021.08.19.21262269; this version posted August 21, 2021. The copyright holder for this preprint (which was not certified by peer review) is the author/funder, who has granted medRxiv a license to display the preprint in perpetuity.

All rights reserved. No reuse allowed without permission.

which has a higher risk of mortality. It is important that interventions should target these vulnerable groups.

The overall mortality rate was $10 \%$ and over two-thirds of children who died presented with gastroenteritis which encompasses vomiting and diarrhoea. Gastroenteritis was also prevalent in the malnourished population which also had the highest mortality. Diarrhoea is a a risk factor of mortality which worsens with malnutrition and HIV co-infection (28). HIV infection is a risk factor to malnutrition and increases susceptibility to persistent diarrhoea and opportunistic infection, greatly impacting on mortality of hospitalised malnourished children (27). In our study, HIV co-infection was higher in children with SAM and MAM (28\% and $29 \%$ ) compared to NAM (3\%) groups.

Malnutrition was present in over half $(61 \%)$ of the study population and $43 \%$ had severe malnutrition. This was higher compared to other countries within the region $(6,15,23)$ and is reflective of the high malnutrition burden in Malawi which has $37 \%$ stunting in children under five years of age (24). It is also worth noting that participants that met criteria for NAM still had a mean weight-for-height $z$ score of -0.6 despite having a normal mean MUAC. Less than two-thirds $(63 \%)$ of children with SAM from the main study had a blood culture collected during admission despite the hospital's recommendations to have blood culture in all SAM children on admission. Failure to recognise SAM on admission leads to failure to adhere to protocols for management of children with SAM (22). The difficulty of venepuncture in this population due to oedema or severe wasting and parents' refusal to consent for blood collection also contributed to the lower than targeted blood culture collection rates.

The prevalence of bacteraemia was $11 \%$ among children with SAM in our study, higher than those in other nutrition groups. This is comparable to most studies in Sub-Saharan Africa $(23,25-27)$. Mortality in our study was higher in children with than without bacteraemia (38\% vs $7 \%$ ) which aligns with findings in other African studies $(5,15,18,25)$. Fever was less common in children compared to those without bacteraemia (62\% vs $86 \%, p=0.017)$, 
medRxiv preprint doi: https://doi.org/10.1101/2021.08.19.21262269; this version posted August 21, 2021. The copyright holder for this preprint (which was not certified by peer review) is the author/funder, who has granted medRxiv a license to display the preprint in perpetuity.

All rights reserved. No reuse allowed without permission.

possibly because of the depressed immune response among SAM children who accounted for the highest proportion of bacteraemia.

Gram negative bacteria were the predominant isolates from the community acquired infections in children with SAM, including E. coli, Salmonella Typhimurium and E. cloacae. These enteric pathogens are commonly described in the SAM population, where gut integrity is compromised (27-29). These isolates were resistant to Gentamicin, a first-line antibiotic in our setting. Our results, similar to a recent study in Tanzania (11), but different from older African studies $(12,25,30,31)$, indicate the emerging issue of antibiotic resistance in SubSaharan Africa. All isolated pathogens with the exception of Salmonella Typhimurium were resistant to Ceftriaxone. Among hospitalised under 5 children at $\mathrm{QECH}$, we documented a rise in resistance to first-line antibiotics from 3.4\% to $30.2 \%$ between 1998 to 2017 (32). Possible reasons for rising resistance to antibiotics are injudicious use of antibiotics during pre-referral management of patients (over $30 \%$ of the patients received antibiotics within 7 days before admission to our study hospital) inappropriate prescribing and excessive use of broad-spectrum antibiotics.

We identified two hospital-acquired bloodstream infections, K. pneumoniae and Candida species which is similar to a South African study which found K. pneumoniae, Candida and Acinetobacter as the predominant hospital acquired infections (33). The resistance of $K$. pneumoniae to both first- and second-line antibiotics has been noted in other high and low income settings (11,34-36) and presents a huge challenge with developing effective empirical regimens in settings with limited diagnostics, constrained supply and variety, and rising rates of antimicrobial resistance. Nosocomial infections are also of increasing concern as other studies have shown high mortality and association with prolonged hospital stay (37). Given high rates of resistance shown in the current and previous studies, blood culture should be collected in all SAM patients on admission to ensure administration of appropriate antibiotics, and which can reduce mortality and morbidity in this population. 
The main limitations of the study include the small number of children with a blood culture taken/convenience sampling, which limits our ability to generalise. However, this is offset by the strengths of the study, which include the detailed clinical data collection and robust diagnostic microbiology.

Findings will inform the development of evidence-based guidelines. There is need for improved diagnostic capacity in low resource settings to meet the challenge of growing AMR worldwide, combined with translational research, clinical trials and antimicrobial stewardships initiatives modified for implementation in low resource settings, to build an evidence-base to inform management of malnourished children.

\section{Conclusion}

Mortality and bacteraemia rates are highest in hospitalised children with SAM. Despite this, these children do not present with typical clinical features including fever, vomiting and convulsions. Given the high rate of antimicrobial resistance in this setting, a high index of clinical suspicion for infection before starting antibiotics, awareness of local susceptibility patterns and evidence-based antibiotic guidelines are needed to optimise clinical care and antimicrobial stewardship.

\section{Acknowledgements}

We wish to express our appreciation to all study participants, CHAIN members of staff particularly Isabel Potani, Allison Daniel and Emmanuel Chimwezi; MLW laboratory staff and James Chirombo.

\section{Funding}

This work was supported by Bill and Melinda Gates Foundation (OPP 1191165 and 11313320) and by MLW Programme 303 Core Award (Grant 206454) from the Wellcome Trust. 


\section{Conflict of interests}

Pui-Ying Iroh Tam has received grants from Bill and Melinda Gates Foundation outside of the submitted work.

\section{References}

1. Black RE, Victora CG, Walker SP, Bhutta ZA, Christian P, De Onis M, et al. Maternal and child undernutrition and overweight in low-income and middle-income countries [Internet]. Vol. 382, The Lancet. Lancet Publishing Group; 2013 [cited 2020 Oct 1]. p. 427-51. Available from: http://www.thelancet.com/article/S014067361360937X/fulltext

2. Independence Experts Group. Global Nutrition Report [Internet]. The Global Nutrition Report's Independent Expert Group. 2020. 168 p. Available from:

https://globalnutritionreport.org/reports/2020-global-nutrition-report/

3. Walson JL, Berkley JA. The impact of malnutrition on childhood infections. Curr Opin Infect Dis. 2018;31(3):231-6.

4. Kuppermann N. Occult bacteremia in young febrile children. Pediatr Clin North Am. 2000 Jan;46:1073-109.

5. Bachou H, Tylleskär T, Kaddu-Mulindwa DH, Tumwine JK. Bacteraemia among severely malnourished children infected and uninfected with the human immunodeficiency virus-1 in Kampala, Uganda. BMC Infect Dis. 2006;6:1-7.

6. Reed RP, Wegerhoff FO, Rothberg AD. Bacteraemia in malnourished rural African children. Ann Trop Paediatr [Internet]. 1996 [cited 2020 Oct 5];16(1):61-8. Available from: https://pubmed.ncbi.nlm.nih.gov/8787368/

7. Babirekere-Iriso E, Musoke P, Kekitiinwa A. Bacteraemia in severely malnourished children in an HIV-endemic setting. Ann Trop Paediatr [Internet]. 2006 Dec [cited 2020 Oct 11];26(4):319-28. Available from:

https://www.tandfonline.com/doi/abs/10.1179/146532806X152845 
medRxiv preprint doi: https://doi.org/10.1101/2021.08.19.21262269; this version posted August 21, 2021. The copyright holder for this preprint (which was not certified by peer review) is the author/funder, who has granted medRxiv a license to display the preprint in perpetuity.

All rights reserved. No reuse allowed without permission.

8. Jones KDJ, Berkley JA. Severe acute malnutrition and infection. Paediatr Int Child Health [Internet]. 2014 Dec 1 [cited 2021 Mar 19];34(Suppl 1):S1-29. Available from: /pmc/articles/PMC4266374/

9. Williams PCM, Berkley JA. Guidelines for the treatment of severe acute malnutrition: a systematic review of the evidence for antimicrobial therapy. Paediatr Int Child Health [Internet]. 2018;38:S32-49. Available from:

https://doi.org/10.1080/20469047.2017.1409453

10. Nalwanga D, Musiime V, Kizito S, Kiggundu JB, Batte A, Musoke P, et al. Mortality among children under five years admitted for routine care of severe acute malnutrition: A prospective cohort study from Kampala, Uganda. BMC Pediatr. $2020 ; 20(1): 1-11$.

11. Ahmed M, Mirambo MM, Mushi MF, Hokororo A, Mshana SE. Bacteremia caused by multidrug-resistant bacteria among hospitalized malnourished children in Mwanza, Tanzania: A cross sectional study. BMC Res Notes. 2017 Jan 25;10(1).

12. Hill PC, Onyeama CO, Ikumapayi UN, Secka O, Ameyaw S, Simmonds N, et al. Bacteraemia in patients admitted to an urban hospital in West Africa. BMC Infect Dis [Internet]. 2007 Dec 26 [cited 2020 Oct 12];7(1):2. Available from: https://bmcinfectdis.biomedcentral.com/articles/10.1186/1471-2334-7-2

13. Alem A. ORIGINAL ARTICLE AMONG SEVERELY MALNOURISHED CHILDREN IN JIMMA UNIVERSITY HOSPITAL , ETHIOPIA.

14. Babirekere-Iriso E, Musoke P, Kekitiinwa A. Bacteraemia in severely malnourished children in an HIV-endemic setting. Ann Trop Paediatr [Internet]. 2006 Dec [cited 2020 Oct 1];26(4):319-28. Available from: https://pubmed.ncbi.nlm.nih.gov/17132297/

15. Abrha A, Abdissa A, Beyene G, Getahun G, Girma T. Bacteraemia among severely malnourished children in jimma university hospital, ethiopia. Ethiop J Health Sci [Internet]. 2011;21(3):175-82. Available from: 
medRxiv preprint doi: https://doi.org/10.1101/2021.08.19.21262269; this version posted August 21, 2021. The copyright holder for this preprint (which was not certified by peer review) is the author/funder, who has granted medRxiv a license to display the preprint in perpetuity.

All rights reserved. No reuse allowed without permission.

http://www.ncbi.nlm.nih.gov/pubmed/22434997\%0Ahttp://www.pubmedcentral.nih.gov /articlerender.fcgi?artid=PMC3275866

16. Office NS. MALAWI POPULATION AND HOUSING CENSUS REPORT-2018 2018

Malawi Population and Housing Main Report. 2019;(May). Available from:

http://www.nsomalawi.mw/images/stories/data_on_line/demography/census_2018/20

18 Malawi Population and Housing Census Main Report.pdf

17. Molyneux EM, Langton J, Njiram'madzi J, Robertson AM. Setting up and running a paediatric emergency department in a hospital in Malawi: 15 years on. BMJ Paediatr Open. 2017;1(1):1-8.

18. Sadler K, Kerac M, Collins S, Khengere H, Nesbitt A. Improving the management of severe acute malnutrition in an area of high HIV prevalence. J Trop Pediatr. 2008;54(6):364-9.

19. Childhood T, Illness A, Network N. Childhood Acute Illness and Nutrition (CHAIN) Network: a protocol for a multi-site prospective cohort study to identify modifiable risk factors for mortality among acutely ill children in Africa and Asia. BMJ Open. 2019;9(5):e028454.

20. Iroh Tam P-Y, Musicha P, Kawaza K, Cornick J, Denis B, Freyne B, et al. Emerging Resistance to Empiric Antimicrobial Regimens for Pediatric Bloodstream Infections in Malawi (1998-2017). Clin Infect Dis. 2019 Jun;69(1):61-8.

21. Vonasek BJ, Chiume M, Crouse HL, Mhango S, Kondwani A, Ciccone EJ, et al. Risk factors for mortality and management of children with complicated severe acute malnutrition at a tertiary referral hospital in Malawi. Paediatr Int Child Health. 2020;

22. Vonasek BJ, Chiume M, Crouse HL, Mhango S, Kondwani A, Ciccone EJ, et al. Risk factors for mortality and management of children with complicated severe acute malnutrition at a tertiary referral hospital in Malawi. Paediatr Int Child Health [Internet]. 2020 Jul 2 [cited 2021 Jun 11];40(3):148-57. Available from: 
https://pubmed.ncbi.nlm.nih.gov/32242509/

23. Ahmed M, Mirambo MM, Mushi MF, Hokororo A, Mshana SE. Bacteremia caused by multidrug-resistant bacteria among hospitalized malnourished children in Mwanza, Tanzania: A cross sectional study. BMC Res Notes. 2017;10(1):1-5.

24. National Statistical Office. Malawi Demographic and Health Survey 2015-16. Natl Stat Off DHS Progr [Internet]. 2015;1-658. Available from:

http://dhsprogram.com/pubs/pdf/FR319/FR319.pdf

25. Reed RP, Wegerhoff FO, Rothberg AD. Bacteraemia in malnourished rural African children. Ann Trop Paediatr [Internet]. 1996 [cited 2020 Oct 11];16(1):61-8. Available from: https://www.tandfonline.com/doi/abs/10.1080/02724936.1996.11747805

26. Nhampossa T, Sigaúque B, MacHevo S, MacEte E, Alonso P, Bassat Q, et al. Severe malnutrition among children under the age of 5 years admitted to a rural district hospital in southern Mozambique. Public Health Nutr. 2013;16(9):1565-74.

27. Okomo UA, Garba D, Fombah AE, Secka O, Ikumapayi UNA, Udo JJ, et al. Bacterial Isolates and Antibiotic Sensitivity among Gambian Children with Severe Acute Malnutrition. Int J Pediatr. 2011;2011:1-8.

28. Norton EB, Archibald LK, Nwanyanwu OC, Kazembe PN, Dobbie H, Reller LB, et al. Clinical predictors of bloodstream infections and mortality in hospitalized Malawian children. Pediatr Res. 2004;23(2):145-51.

29. Babirekere-Iriso E, Musoke P, Kekitiinwa A. Bacteraemia in severely malnourished children in an HIV-endemic setting. Ann Trop Paediatr [Internet]. 2006 Dec [cited 2021 Mar 19];26(4):319-28. Available from: https://pubmed.ncbi.nlm.nih.gov/17132297/

30. Noorani N, Macharia WM, Oyatsi D, Revathi G. Bacterial isolates in severely malnourished children at Kenyatta National Hospital, Nairobi. East Afr Med J. 2005 Jul;82(7):343-8. 
31. Abrha A, Abdissa A, Beyene G, Getahun G, Girma T. Bacteraemia among severely malnourished children in jimma university hospital, ethiopia. Ethiop J Health Sci [Internet]. 2011 Nov [cited 2021 Mar 19];21(3):175-82. Available from: http://www.ncbi.nlm.nih.gov/pubmed/22434997

32. Tam PYI, Musicha P, Kawaza K, Cornick J, Denis B, Freyne B, et al. Emerging resistance to empiric antimicrobial regimens for pediatric bloodstream infections in Malawi (1998-2017). Clin Infect Dis. 2019;69(1):61-8.

33. Dramowski A, Cotton MF, Rabie H, Whitelaw A. Trends in paediatric bloodstream infections at a South African referral hospital. BMC Pediatr [Internet]. 2015 Apr 2 [cited 2020 Oct 12];15(1):33. Available from:

http://bmcpediatr.biomedcentral.com/articles/10.1186/s12887-015-0354-3

34. Bejon P, Mwangi I, Ngetsa C, Mwarumba S, Berkley JA, Lowe BS, et al. Invasive Gram-negative bacilli are frequently resistant to standard antibiotics for children admitted to hospital in Kilifi, Kenya. J Antimicrob Chemother. 2005;56(1):232-5.

35. Schaffner J, Chochua S, Kourbatova E V., Barragan M, Wang YF, Blumberg HM, et al. High mortality among patients with positive blood cultures at a Children's Hospital in Tbilisi, Georgia. J Infect Dev Ctries. 2009;3(4):267-72.

36. Zhang Y, Guo LY, Song WQ, Wang Y, Dong F, Liu G. Risk factors for carbapenemresistant K. pneumoniae bloodstream infection and predictors of mortality in Chinese paediatric patients. BMC Infect Dis. 2018;18(1):1-10.

37. Aiken AM, Mturi N, Njuguna P, Mohammed S, Berkley JA, Mwangi I, et al. Risk and causes of paediatric hospital-acquired bacteraemia in Kilifi District Hospital, Kenya: A prospective cohort study. Lancet [Internet]. 2011 [cited 2021 Mar 19];378(9808):2021-7. Available from: /pmc/articles/PMC3242162/ 
medRxiv preprint doi: https://doi.org/10.1101/2021.08.19.21262269; this version posted August 21, 2021. The copyright holder for this preprint (which was not certified by peer review) is the author/funder, who has granted medRxiv a license to display the preprint in perpetuity.

All rights reserved. No reuse allowed without permission.

\section{Figure Legends}

Figure 1. Participants' flow diagram

MAM, Moderate Acute Malnutrition; NAM, No Acute Malnutrition; SAM, Severe Acute Malnutrition

Figure 2. Isolates from different nutrition groups

MAM, Moderate Acute Malnutrition; NAM, No Acute Malnutrition; SAM, Severe Acute Malnutrition

\section{Supplemental material}

Supplemmentary table 1. Clinical characteristics and outcomes of SAM patients who had a positive and negative blood culture 
medRxiv preprint doi: https://doi.org/10.1101/2021.08.19.21262269; this version posted August 21, 2021. The copyright holder for this preprint (which was not certified by peer review) is the author/funder, who has granted medRxiv a license to display the preprint in perpetuity.

All rights reserved. No reuse allowed without permission.

Table 1. Comparison of clinical characteristics and outcomes among CHAIN patients who had blood culture obtained on admission, stratified by nutrition status

\begin{tabular}{lllll}
\hline & NAM (N=69) & MAM (N=31) & SAM (N=75) & P value \\
\hline Sex (Male) & $38(55 \%)$ & $19(61 \%)$ & $45(60 \%)$ & 0.779 \\
\hline Age & & & & 0.039 \\
\hline Mean months (SD) & $13(6)$ & $10(5)$ & $12(6)$ & \\
\hline Range & $2.0-23.0$ & $2.0-23.0$ & $0.0-23.0$ & \\
\hline Weight for Height & & & & \\
\hline Mean Z-Scores (SD) & $-0.6(1.2)$ & $-2.0(1.0)$ & $-3.2(1.4)$ & \\
\hline Oedema & $0(0 \%)$ & $0(0 \%)$ & $13(17 \%)$ & $<0.001$ \\
\hline Presenting Complaints & & & & \\
\hline Fever & $68(99 \%)$ & $28(90 \%)$ & $52(69 \%)$ & $<0.001$ \\
\hline Vomiting & $32(46 \%)$ & $25(81 \%)$ & $28(37 \%)$ & $<0.001$ \\
\hline Lethargy & $9(13 \%)$ & $4(13 \%)$ & $4(5 \%)$ & 0.238 \\
\hline Diarrhoea <14 days & $23(33 \%)$ & $20(65 \%)$ & $40(53 \%)$ & $\mathbf{0 . 0 0 6}$ \\
\hline Convulsions & $20(29 \%)$ & $3(10 \%)$ & $1(1 \%)$ & $<0.001$ \\
\hline Cough <14 days & $37(54 \%)$ & $18(58 \%)$ & $38(51 \%)$ & 0.782 \\
\hline
\end{tabular}

Medications taken within 7 days prior to admission

\begin{tabular}{lllll}
\hline Antibiotic & $26(38 \%)$ & $10(32 \%)$ & $33(44 \%)$ & 0.494 \\
\hline Antimalarial & $5(7 \%)$ & $0(0 \%)$ & $1(1 \%)$ & 0.077 \\
\hline Paracetamol or Ibuprofen & $24(35 \%)$ & $7(23 \%)$ & $22(29 \%)$ & 0.457
\end{tabular}

HIV Status

0.061

\begin{tabular}{lccc}
\hline PCR positive & $0(0 \%)$ & $1(3 \%)$ & $7(9 \%)$ \\
\hline Antibody positive, unknown & $2(3 \%)$ & $8(26 \%)$ & $14(19 \%)$ \\
PCR status & &
\end{tabular}

\section{Admission Clinical Diagnosis}


medRxiv preprint doi: https://doi.org/10.1101/2021.08.19.21262269; this version posted August 21, 2021. The copyright holder for this preprint (which was not certified by peer review) is the author/funder, who has granted medRxiv a license to display the preprint in perpetuity. All rights reserved. No reuse allowed without permission.

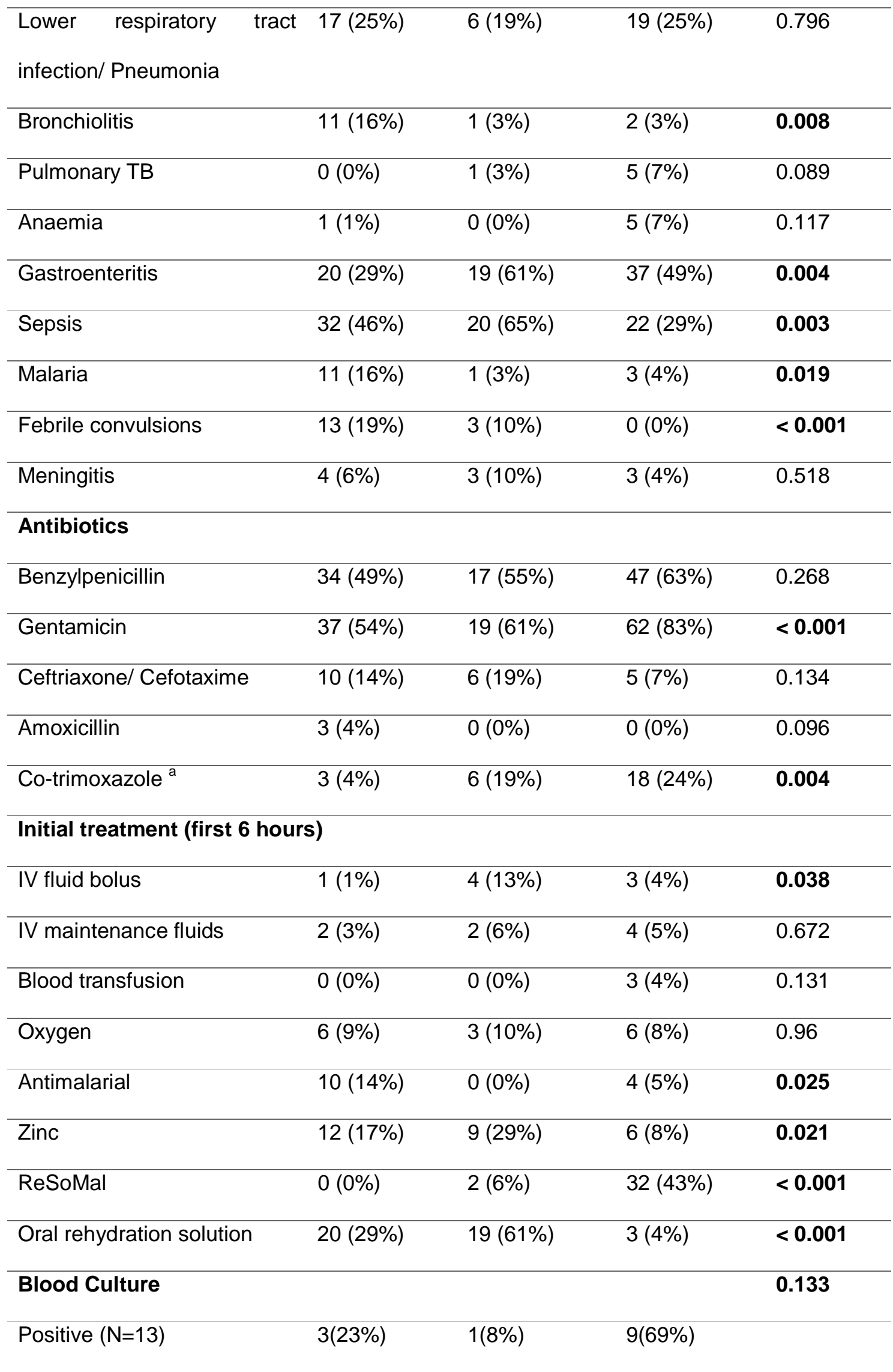


medRxiv preprint doi: https://doi.org/10.1101/2021.08.19.21262269; this version posted August 21, 2021. The copyright holder for this preprint (which was not certified by peer review) is the author/funder, who has granted medRxiv a license to display the preprint in perpetuity.

All rights reserved. No reuse allowed without permission.

\section{Outcomes}

\begin{tabular}{lllll}
\hline Hospital stay & & & $<0.001$ \\
\hline Mean days (SD) & $3(2)$ & $5(5)$ & $10(7)$ & \\
\hline Range & $0.0-11.0$ & $1.0-21.0$ & $1.0-36.0$ & \\
\hline Died & $1(1 \%)$ & $2(6 \%)$ & $14(19 \%)$ & $\mathbf{0 . 0 0 2}$
\end{tabular}

CHAIN: Childhood Acute Illness Network; MAM, Moderate Acute Malnutrition; NAM, No Acute Malnutrition; SAM, Severe Acute Malnutrition

${ }^{a}$ Co-trimoxazole prophylaxis commenced or continued on admission.

Table 2. Characteristics and outcomes of patients who had a positive and negative 


\section{blood culture}

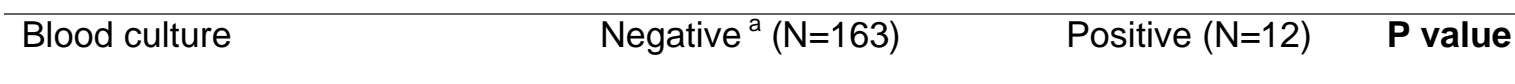

\section{Clinical characteristics}

\begin{tabular}{lccc}
\hline Fever & $141(87 \%)$ & $7(58 \%)$ & 0.009 \\
\hline Diarrhoea (<14 days) & $77(47 \%)$ & $6(50 \%)$ & 0.853 \\
\hline Poor feeding & $46(28 \%)$ & $6(50 \%)$ & 0.111 \\
\hline Pneumonia & $39(24 \%)$ & $3(25 \%)$ & 0.933 \\
\hline Sepsis & $69(42 \%)$ & $5(42 \%)$ & 0.964 \\
Antibiotics in the past 7 & $60(37 \%)$ & $9(75 \%)$ & 0.009 \\
days & & & \\
\hline
\end{tabular}

\section{Outcomes}

Hospital stay

0.194

\begin{tabular}{lccc}
\hline Mean days (SD) & $6.1(6.0)$ & $8.5(6.9)$ & \\
\hline Range & $0.0-36.0$ & $2.0-26.0$ & \\
\hline Died & $13(8 \%)$ & $4(33 \%)$ & 0.004 \\
\hline
\end{tabular}

${ }^{a}$ No growth or non-significant growth or isolate other than bacteria 
medRxiv preprint doi: https://doi.org/10.1101/2021.08.19.21262269; this version posted August 21, 2021. The copyright holder for this preprint (which was not certified by peer review) is the author/funder, who has granted medRxiv a license to display the preprint in perpetuity.

All rights reserved. No reuse allowed without permission.

Table 3. Sensitivity profiles of the blood culture isolates

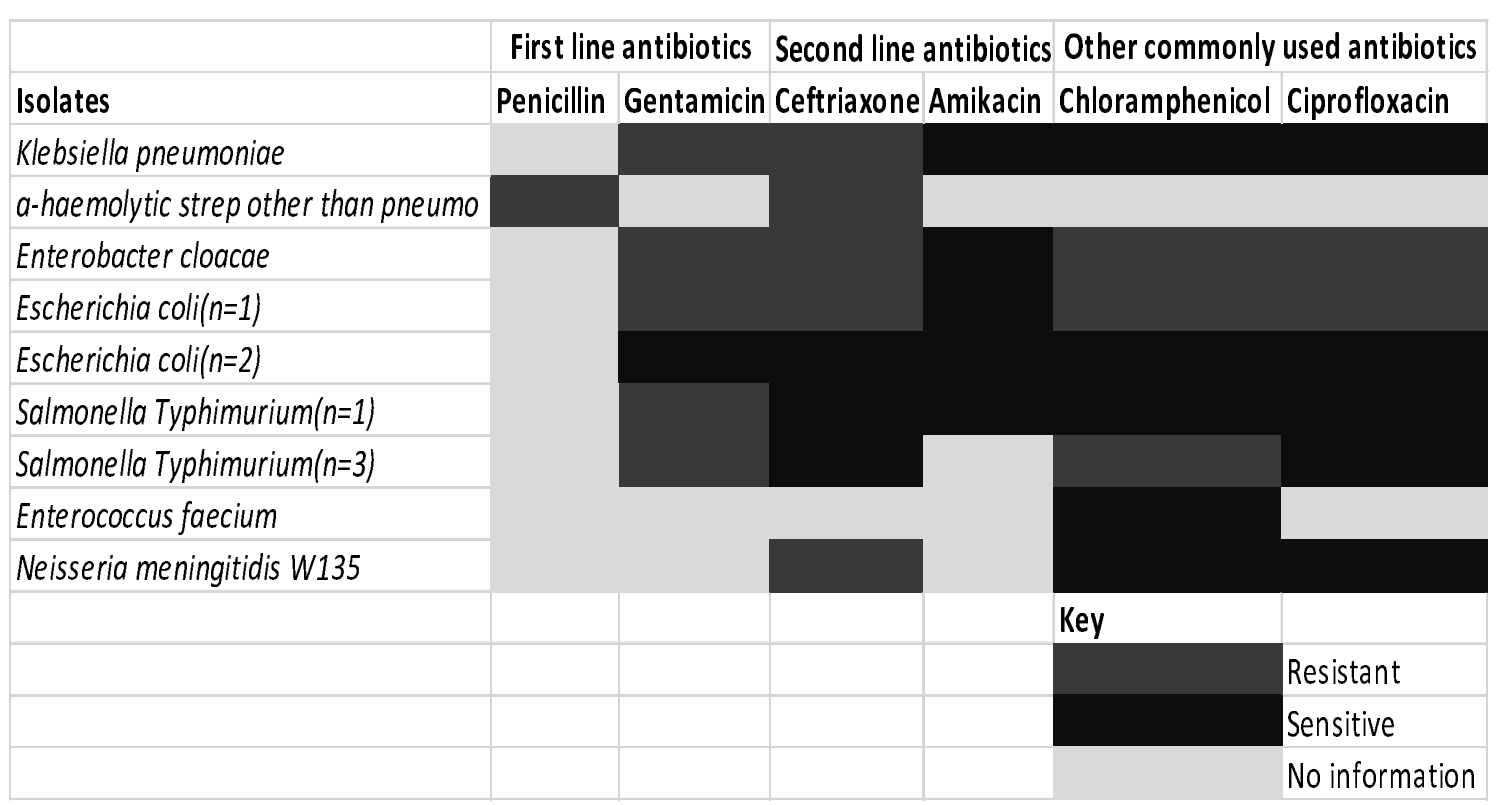


medRxiv preprint doi: https://doi.org/10.1101/2021.08.19.21262269; this version posted August 21, 2021. The copyright holder for this preprint (which was not certified by peer review) is the author/funder, who has granted medRxiv a license to display the preprint in perpetuity.

All rights reserved. No reuse allowed without permission.

Table 4. Clinical characteristics of patients who were discharged compared to those who died

\section{Discharged $(\mathrm{N}=158) \quad$ Died $(\mathrm{N}=17) \quad P$ value}

\section{Clinical characteristics}

\begin{tabular}{lccc}
\hline Fever & $137(87 \%)$ & $11(65 \%)$ & 0.017 \\
\hline Difficulty breathing & $45(28 \%)$ & $6(35 \%)$ & 0.557 \\
\hline Pneumonia & $38(24 \%)$ & $4(24 \%)$ & 0.962 \\
\hline Gastroenteritis & $64(41 \%)$ & $12(71 \%)$ & 0.017 \\
\hline Sepsis & $68(43 \%)$ & $6(35 \%)$ & 0.539 \\
\hline Antibiotic in past 7 days & $61(39 \%)$ & $8(47 \%)$ & 0.498 \\
\hline Hospital stay & & & 0.616 \\
\hline Mean days (SD) & $9.4(6.6)$ & $8.6(6.4)$ & \\
\hline Range & $1.0-25.0$ & $1.0-22.0$ & \\
\hline
\end{tabular}


medRxiv preprint doi: https://doi.org/10.1101/2021.08.19.21262269; this version posted August 21, 2021. The copyright holder for this preprint (which was not certified by peer review) is the author/funder, who has granted medRxiv a license to display the preprint in perpetuity.

All rights reserved. No reuse allowed without permission.

\section{Identification}

Analysis

Nutrition stratification

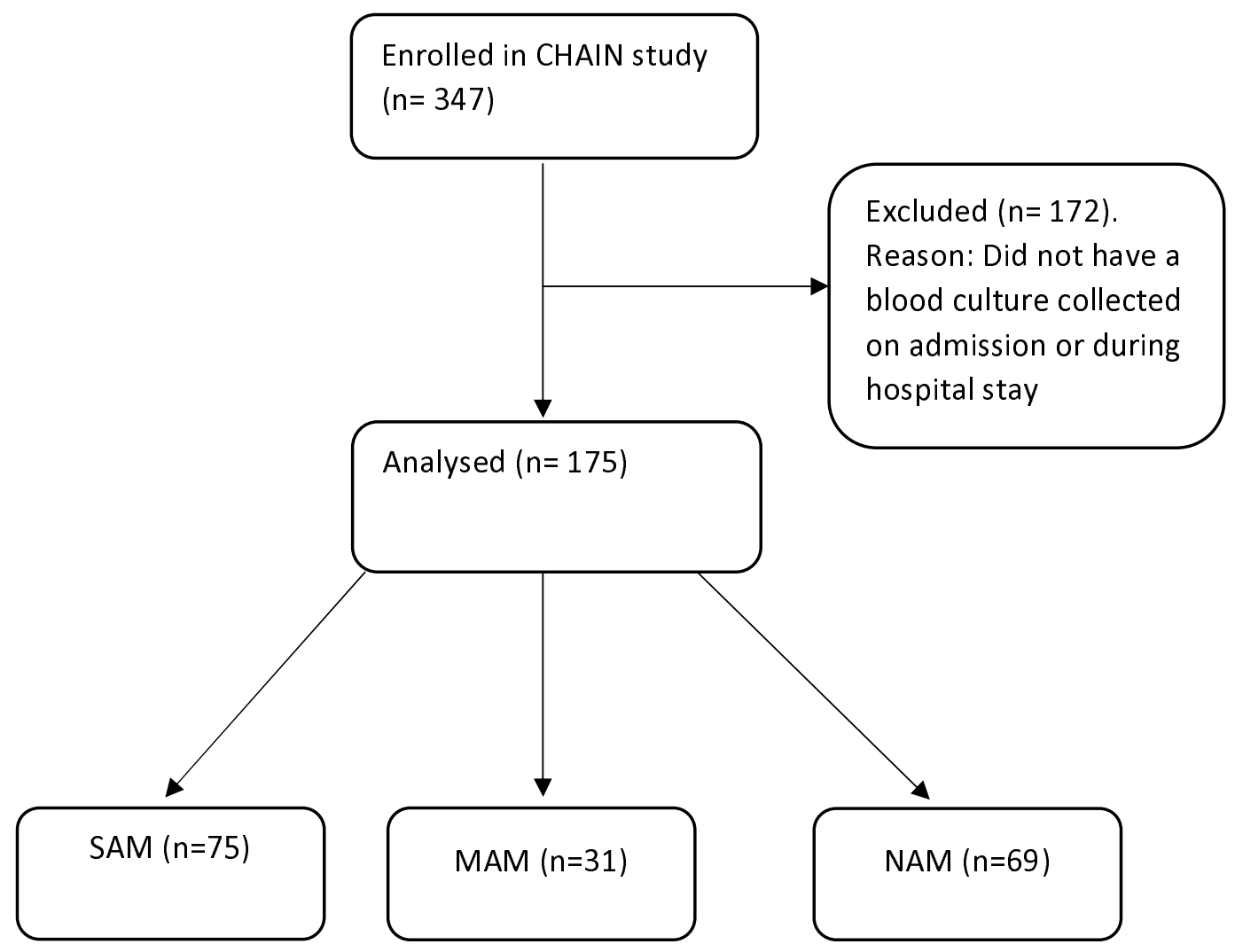


medRxiv preprint doi: https://doi.org/10.1101/2021.08.19.21262269; this version posted August 21, 2021. The copyright holder for this preprint (which was not certified by peer review) is the author/funder, who has granted medRxiv a license to display the preprint in perpetuity.

All rights reserved. No reuse allowed without permission.

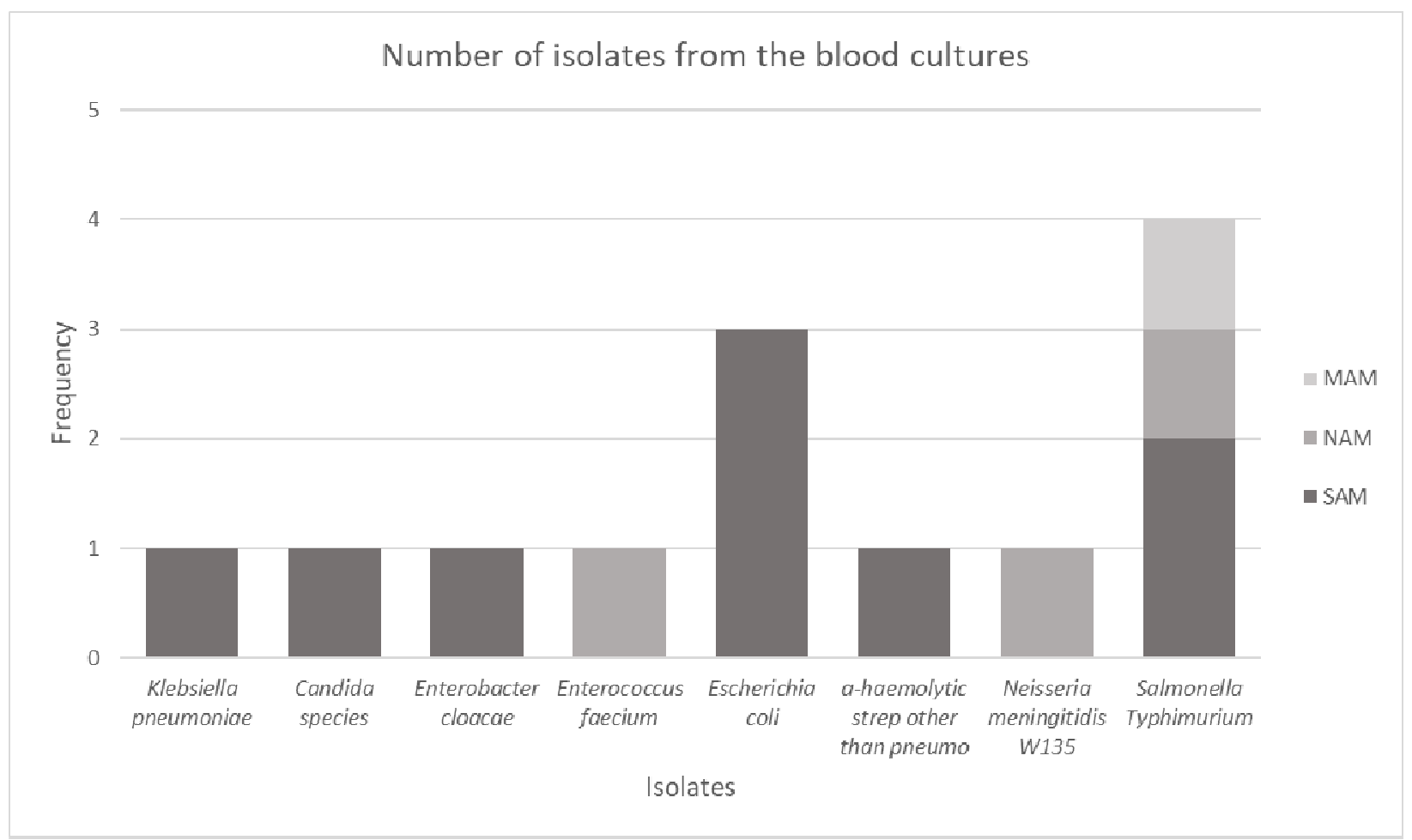

